Año L. urtea

$125-2018$

Urtarrila-ekaina Enero-junio

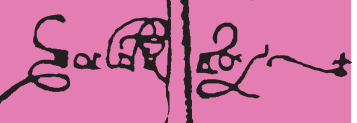

(ans

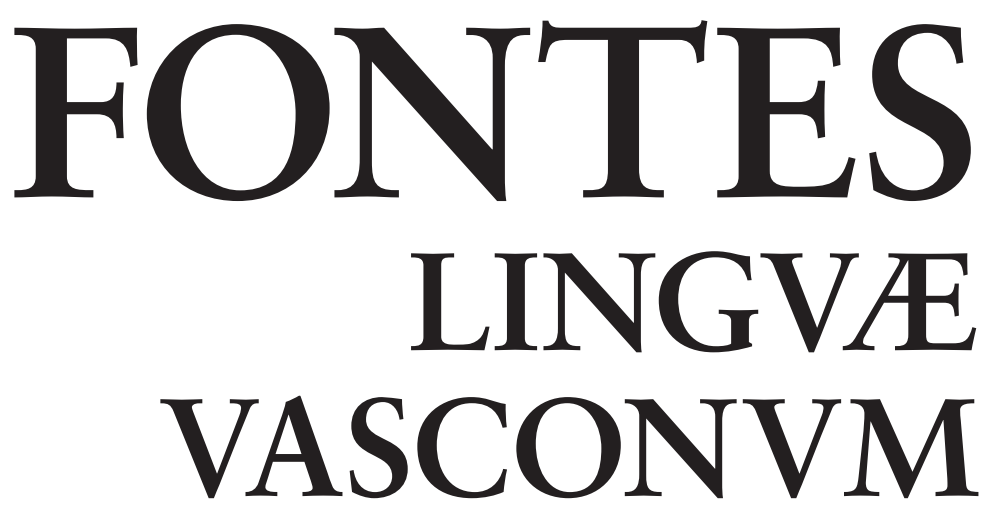

STVDIA ET DOCVMENTA

SEPARATA

\section{Jean Etxepare eta Pío Baroja}

Aitor Ortiz de Pinedo

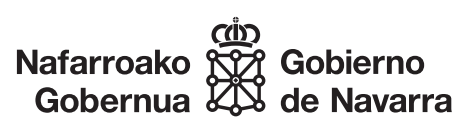

0000 


\title{
Jean Etxepare eta Pío Baroja
}

\author{
Jean Etxepare y Pío Baroja
}

Jean Etxepare and Pío Baroja

Aitor ORTIZ DE PINEDO

Euskal Herriko Unibertsitatea, UPV/EHU \& Université Bordeaux-Montaigne

aortizpinedo@gmail.com

Beribilez aztertzeko orduan eta artikulu hau idatzi ahal izateko hainbat iradokizun zor dizkiet Jon Kortazar eta Jon Casenave tesi-zuzendariei, azken horri artikuluaren gaia barne, aipatzeke utzi gabe zirriborroaren ebaluatzaile anonimo prestuak FLV aldizkari honetan.

Jasotze data: 08/01/2018. Behin-behineko onartze data: 25/01/2018. Behin betiko onartze data: 26/02/2018. 


\section{LABURPENA}

Artikulu hau Jean Etxepareren Beribilez (1931) liburuari buruzko tesi baten jarraipena da. Hari nagusia da Jean Etxepareren eta Pío Barojaren arteko paralelismo bat egitea, zenbait berdintasun eta alde zerrendatuta. Paralelismoa, batez ere, idazle bi horien euskal alderdi identitarioari dagokio, nahiz eta sartu-irten bat edo beste ere egingo den haien ikuspegi filosofikoetan. Bi idazleak garaikideak dira eta Europako pentsamendu-giro beraren zordun, ahaztu gabe biek adierazten duten euskaltzaletasun konpartitua, zentzurik zabalenean. Azpimarratzekoak dira, bestalde, bi idazleon obrek izan zituzten gizarte-harrera bereziak, eta idazleon jarrera-desberdintasunak egia adierazteko, kontuan izanik bakoitzak zuen irakurlegoaren izaera, bata euskalduna eta bestea erdalduna.

Gako hitzak: Jean Etxepare; Pío Baroja; laikotasuna; literatura konparatua; heterodoxia.

\section{RESUMEN}

Este artículo es continuación de un completo estudio para una tesis doctoral sobre el libro de Jean Etxepare Beribilez (1931). Se realiza un estudio comparativo entre Jean Etxepare y Pío Baroja con el objeto de encontrar coincidencias y diferencias. Esta investigación se basa principalmente en su ideología identitaria vasca, aunque también se presta atención a cuestiones filosóficas. Los dos escritores son parte del mismo ambiente intelectual europeo, y ambos son empáticos con el País Vasco. Se puede decir que su obra literaria estuvo determinada por el perfil de sus lectores hipotéticos, ya que Jean Etxepare escribió principalmente para hablantes de euskera y Pío Baroja dirigió sus escritos a los españoles.

Palabras clave: Jean Etxepare; Pío Baroja; laicidad; literatura comparada; heterodoxia.

\section{ABSTRACT}

This article comes after a thorough study for a $\mathrm{PhD}$ dissertation on a book by Jean Etxepare (Beribilez, 1931). A comparative study is drawn between Jean Etxepare and Pío Baroja with the aim of finding their coincidences and differences. This research is based mostly in their basque identitary ideology, even though some attention is also paid to some philosophical issues. Both writers are part of the same European intellectual ambiance, and both are empathetic to the Basque Country. Broadly speaking, it can be said that their literary work was heavily determined by the profile of their hypothetical readers, as Jean Etxepare wrote mainly for Basque language speakers and Pío Baroja addressed his writings to Spanish ones.

Keywords: Jean Etxepare; Pío Baroja; laicity; comparative literature; heterodoxy. 
1. SARRERA: IDAZLE GARAIKIDE BI. 1.1. Mediku euskaldun bi. 1.2. Zalduntxoen bidetik. 2. PAReKotasunak ETA AldeAK. 2.1. Parekotasunak. 2.1.1. Heterodoxia. 2.1.2. Euskal Herriaren iruditeria. 2.2. Aldeak. 2.2.1. Paisaia idazten. 2.2.2. Euskararen dilema. 3. ONDORIOAK. 4. ERREFERENTZIAK.

\section{SARRERA: IDAZLE GARAIKIDE BI}

\subsection{Mediku euskaldun bi}

Jean Etxepareren aurkezpen laburra dagokigu egitea, artikuluaren gai zehatzagora igaro orduko. Jean Etxepare Bidegorri (1877-1935) medikua izan zen ogibidez, gehienbat Nafarroa Behereko Alduden eta Kanbon aritua lanean. Horrez gain, Euskaltzaleen Biltzarreko burulehena izan zen 1920ko hamarkadan zenbait urtez. Idatzi ere franko egin zuen: bereziki liburu gogoangarri bi (Buruxkak, 1910; Beribilez, 1931), eta hainbat kazeta-artikulu, besteak beste, Piarres Charrittonek (1984-1996) Jean Etchepare mirikuaren (1877-1935) idazlanak izeneko bost liburukitan bilduak. Medikuari buruzko kritika-lan nagusi batzuk izan dira (Lafitte, 1941; Casenave, 2002; Altonaga, 2006); Jon Casenaveren ikerketa Buruxkaken finkatu bada ere, esan liteke Beribilez idazlearen bigarren liburua ez duela kritikak orain arte modu sakonean irakurri. Hori izan da gure apustua (Ortiz de Pinedo, 2018). Gaingiroki, esan beharra dago medikuaren bi liburuek harrera mugatu samarra izan zutela, hala arrazoi literarioengatik, nola beste ideologikoago batzuengatik ${ }^{1}$.

1 Beribilez aztertzeko orduan eta artikulu hau idatzi ahal izateko hainbat iradokizun zor dizkiet Jon Kortazar eta Jon Casenave tesi-zuzendariei, azken horri artikuluaren gaia barne, aipatzeke utzi gabe zirriborroaren ebaluatzaile anonimo prestuak FLV aldizkari honetan. 
Beribilez aztertu izanak bidea eman digu Pío Barojaren (1872-1956) hurbiltasuna sentitzeko gure hasierako ikergaiaren ondoan, donostiarra eta Jean Etxepare alderdi bat baino gehiagotan bidaide eta gogaideak izan zitezkeela-eta. Belaunaldi berekoak ziren eta euskal herritarrak; gainera, beren jaioterriko zerumuga murritzak gaindituta, Europako ondare komuna begiz jo zuten; ordea, idazteko hizkuntza berezi bana zuten. Interesgarria suerta dakioke gaurko irakurleari bi hizkuntzen eta dagozkien gizarteen arteko solasa.

Bi idazleon biografiak kontuan hartuta, zenbait ezaugarri komun badira. Bi autore hauek belaunaldi berekoak izateaz gain denboraren harian, geografikoki ere hurbil egon ziren bizitzako urte askoan. Jean Etxepare Alduden bizi zen hartan, Pío Baroja Bidasoako Beran bizi izan zen Madriletik etorria, eta urtero sei hilabete inguru egiten zituen Itzeako etxean. Ez da txiripa hutsa bi Nafarren arteko muga agertzea, hala Beribilezeko bidaiaren kontakizunean, nola Barojaren Zalacaín el aventurero (1909) eleberri arrakastatsuan. Parekotasunekin jarraituta, biak ziren euskaldunak: bertoko problematika ondo ezagutzen zuten.

Jakina denez, formazioaren aldetik medikuak ziren biak. Biek ezagutu eta miretsiko zuten medikuntza esperimentala, Claude Bernard-en (1813-1878) ideien jarraitzaile agertzen direla.

Euskarazko kritikak ere jaso du Pío Barojaren berria (Mitxelena, 1955; Elkar-lanean, 1972; Mitxelena, 2001; Aldekoa, 2008...). Bi medikuok elkarrekiko antzekotasun asko izanagatik, aldeak ere badituzte. Euskaldunak ziren heinean, Euskal Herriaren iruditeria bana sortu zuten idaztietan. Biak ziren, nolabait esan, heterodoxoak euskal esparru gehienbat monokordean. Hala ere, bakoitzak ezberdina zuen jomugako gizartea mugaren alde banatara: Etxeparek irakurlego euskalduna izanik ere, Barojak gaztelerazkoa zuen.

Hari horretatik, ematen du Etxeparek zedarri estuagoen barnean lan egin eta sortu behar izan zuela Barojak baino. Europako testuinguruan, euskal gizartea are hertsatzailegoa zen, gazteleraz bizi zen gizartea oso liberala ez izanik ere. Etxeparek gorostian gorosti, Donostian Donosti goiburua onartu bazuen ere, helduaroan Hans Reichenbach (1891-1953) enpirista logikoari jarraituz, itxura batean, Barojari zintzotasuna eta zinezkotasuna egokitu dizkio kritikak ezaugarri modura; Barojak «fauno kantianotzat» zeukan bere burua, eta jakitera ausartu (sapere aude) zitekeen. Etxeparek zuhurtzia eta isiltasuna hobetsi behar izan zituen, euskal komunitate teokratiko hartan.

Antzekotasunei eutsiz, bi idazleak ziren antiklerikalak, hau da, politika klerikalaren aurkakoak; ez da harritzeko kontua giroan zegoen keinua baitzen, hala Frantzian, nola Espainian. Pentsamendu landu baten harian, nabaria da bi mediku adinkideek garaieta kultura-giro bera bizitu izan zutela, beti ere nazioarteko kultura jasora iristeko ahalegina egiten zutela. Egiazta daiteke, adibidez, Kant, Schopenhauer, Nietzsche, Bergson, Haeckel, besteak beste, bi idazleek ezagutu zituztela (Baroja, 1918; Lafitte, 1974). Hori euskal idazle laiko batentzat bazen zerbait garai hartan, Etxepareren kasuan, goi mailako heziketa seminarioetan partitzen baitzen. 
Biak intelektualak izan ziren, idazteko moldeari erreparatuz gero: filosofia eta kezka soziala beren arduren artean zeuden. Izan ere, medikua zen Errepublikaren moralaren bultzatzaile prestigioduna zientziaren eta aurrerakuntzaren mezularia Iraultzatik aurrera, medikuntzak gizakia moralki eta fisikoki zaharberritzeko eginkizuna baitzeukan, nahiz eta Frantzian gehiago Espainian baino. Medikua izan zen XIX. aren amaieran katolikotasunaren eta laikotasunaren artean zubia egiten zuena, morala zientziak argituko zuelakoan baitzeuden batzuk (Baubérot, 2004); Etxepareri buruz, hari horretatik, aipatu izan da lanbidea apaizgoa (abnégation) zitzaiola.

Anestesiako medikuntza-praktikak, adibidez, arazo erlijiosoak gainditu behar zituen, heriotzeko biderako kristaua eskatzen ez zuelako, bitxia suertatzen zena gizarte tradizionalean. Bestetik, bekatuaren alderako obsesio gisa kalifikatzen zen gaixoaren lotsa mediku-azterketaren aurrean. Beraz, medikuek bazuten lanik osasunaren arloko aurrerakuntza helarazteko herri ezjakinari, erlijioaren arloan sinesbera, zientziaren arloan sinesgogorra. Horrek guztiak azal lezake, hein batean, bi medikuek gizartea erradiografiatzeko hartu zuten egitekoa eta, halaber, hartu zuten rola modernitatearen ibilbidean, alde batera gizartearen ahuleziak agerian ipinita Émile Zola naturalistak (1840-1902) abian jarritako prozedurari eutsiz.

\subsection{Zalduntxoen bidetik}

Hari komun baten bila saiatu beharko bagenu bi idazle hauek konparatzean, ziurrenez erreparatu beharko genioke euskaltasuna hezurmamitzeko izan zuten modu bereziari, biak parekatu ahal izateko heinekoa bai, baina, aldi berean, biak euskal gizarteko pentsamolde nagusien bazterrean kokatzeko modukoa.

Azaldu da Jean Etxeparek izan zuen bere ideiak pentsamolde nagusiarekin homologatzeko zailtasuna (Casenave, 2002; Apalategi, 2003; Altonaga, 2006). Gauza bera esan liteke Pío Barojaren ikusmoldeari buruz, zeinak oraintsura arte kritikari onbera baten babesa behar izan duen, kristau-federik eza gaurko euskal irakurleen aurrean nola edo hala zuritzeko (Mitxelena, 1972, 273. or.).

Gogoangarria izan daiteke Euskalerriko Adiskideen Elkartea Barojak aldarrikatua Bidasoako Txapelaundien aurreko hitzaldi mitiko hartan (Baroja, 1919), euskaltasun laiko baten ildotik eta Antzinako Errejimena berrikusteko saio baten barnean. Jean Etxeparek ere badu abiaburu esanguratsu bat baino gehiago Azkoitiako ilustratuen jomugetara hurbiltzen duena; adibidez, idazkietan behin eta berriro borrokatzen dituen sineskerien eta basa-medikuntzaren salaketa, zientziaren eta arrazoiaren izenean urrutiago jo gabe, edota aurrerakuntza teknikoa bultzatzeko lehia gizartearen jardun guztietan.

Idazle bi hauen jarrera minoritarioak testuinguru historikoan kokatzeko, komeni da gogoratzea euskal Ilustrazioak Euskalerriko Adiskideen sasoian bertan bilatu behar izan zituen konponbideak Antzinako Errejimeneko ordezkari nagusiekin, Eliza eta aristokrazia bereziki (Artola Renedo, 2009), konpromezu horrek ideia ilustratuak berandutzeko izan zezakeen eragina kontuan hartzekoa izanik: horren erakusgarria da, 
adibidez, Inkisizioak oniritzia eman behar izaten ziela zalduntxoei beren irakurketak hautatzerakoan, Entziklopedia, besteak beste, gaizki ikusia baitzegoen.

Euskal eleberriaren eremuan, Juan Antonio Mogel batek, Peru Abarkaren (1802) sortzailea, argi uzten du zein ziren bere errezeloak gizarte modernoago bati buruz Peru protagonista nagusiaren berbaldietan, bidenabar esanda, ilustratu aurrerakoi batentzat desegokiak kontuan hartuta Euskalerriko Adiskideen artekoa zela Mogel ere (Apalategi, 2004; Aldekoa, 2012; Gartzia, 2015).

Kontuan hartu behar da, esparru zabalago baten markoan, giza eta gizarte-zientziak orduan hasi zirela tokia jaten giza munduaren ikuspegi konfesionalari, gizakia eta gizartea doktrinaren bitartekotzaz azaldu gabe.

\section{PAREKOTASUNAK ETA ALDEAK}

\subsection{Parekotasunak}

\subsubsection{Heterodoxia}

Esan den bezala bi autore hauek badute euskaltasuna ulertzeko modu berritzailea beren sasoian. Antiklerikalak ziren, zilegia bada kalifikatibo horrekin aipatzea biek sentitzen zuten errezeloa Elizaren eskuhartze politiko neurrigabeari buruz. Programa hori ez zen, noski, ez Iparraldeko Elizarena, ezta Hegoaldeko bizkaitarren «teokraziarena» ere, Barojaren ikuspuntua islatzeko beraren hitz hori erabiltzea doia baldin bada.

Bi idazleek bizi zuten giroa marrazteko egokia izan daiteke gogoratzea Elizak eta estatuak zeramaten tirabira luzea, hala Frantzian (Gartzia Trujillo 2016, 97-107. or.) nola Espainian. Biek hautatu zuten ikuspegi aurrerakoia, nolabait deitzeko Erregimen Zaharreko indarren kontra (kleroa eta aristokrazia) hartu zuten jarrera ideologikoari. Laikotasunaren alde zeuden, dudarik gabe; Baroja goraki mintzatu ahal izan zen, nahiz eta Etxepareren kasuan bere benetako ideiak pribatuan soilik eman beharra izan zuen. Eliza krisian zegoen burgesiaren oldarraren aurrean, eta urteak beharko zituen Europako egoera berrira egokitzeko. Zientziak aurrerakuntza handiak egin zituen; berrikuntza modernoak gizartearen esparru denetan hedatu ziren, eta antzinako jokamoldeak zaharkituta geratu ziren; kolonialismoak indar betea hartu zuen. Optimismo horrek indar laikoei erakargarritasun eta tiradizo bereziak emango zizkien, mundu gerrak iritsi bitartean. Elizak ez zuen lortuko egoera berriari gaina hartzea, esan badaiteke, ia Vatikanoko II. Kontziliora arte 1965ean. Etxeparek ezagutu zuen Eliza Trentoko Kontzilioaren oinordekoa zen, oraindik.

Beste arlo batean, aipa daiteke autore bi hauek industria hedatzearen aurrean duten jarrera anbibalentea. Gizarte tradizionala suntsitzeko prozesu kupidagabeak pentsakor jartzen zituen bi idazle hauek; masa-gizarte berriak bizitza-kalitatea porroskatzen zuela iruditzen zitzaien. Jean Etxeparek ez du begi onez ikusten kanpotarrek hartzea bertoko industriaren giderrak. Aldudeko medikuaren ustez, gainera, burgesiaren gidaritza eta nagusigo horiek arrunkeria dakarte berekin; areago, goi burgesiaren harrapakari-izaera ondasungoseak beste gerra baten atean jartzen du Europa, haren ustez: 
horrela sortuko ziren urte gutxi geroago totalitarismoak eta Bigarren Mundu Gerra, Etxeparek profetikoki aurreikusia zuenez Beribilezen, Jean Barbier idazlearen Piarres II (1929) eleberria goraipatzean, gerrari aurre egiteko irakurle gazteari eskaintzen dizkion baliabide moralak direla-eta.

Adierazgarria da oso, era berean, Barojak (Baroja, 2006) eta Etxeparek (Etchepare, 1931, 84. or. eta hh.) Donostiarekiko zuten jarrera. Baroja donostiarra zen, nahiz eta Etxeparek ere hiriaren hazkunde eta bilakaera hurbiletik ezagutuko zuen XX. mendeko lehen herenean: Gipuzkoako hiriburua ezein burubide espiritual eta kulturaletik at somatzen zuten, hiri oparoa Belle Époque ondoko urteetan deskribatu zutela. Bi autoreontzat Donostia zen arimarik eta gizatasunik gabeko goi burgesiaren biltokia, interesik gabea ta arbuiagarria. Paradoxa lirudikeen arren, Etxepare Bilboren hazkunde industrialaren mireslea zen (Altonaga, 2006, 158-161), beharbada bere garaiko beste euskal idazle batzuk ez bezala (Txomin Agirre gogoan), aurrerakuntza industriala begi txarrez zekusatenak, ziur aski, arrazoi erlijioso-moralengandik. Barojak ere Bilboren dinamismoa estimatzen zuen: «La ría es una de las cosas más sugestivas de España» (Baroja 1953, 128. or.). Horretara, badirudi Donostian zekusaten arinkeriazko giroak susmo txarra sortzen ziela.

Bien arteko beste parekotasun bat aipatzearren, gogora daiteke izan zuten porrot soziala. Garai hura intelektualaren sorrerakoa zen, Dreyfus aferak (1894-1906) gizartepanoramako figura berri horri gora eman zionetik. Bazuten biek intelektualak izateko guraria, beren izkribuei erreparatuta nabaria denez. Barojak, izan ere, oin bat jarri zuen Espainiako esfera politikoan Lerroux buruzagi populistaren alderdiarekin arituz, baina ez zuen arrakastarik izan. Etxeparek bere asmo erreformatzaileak ezdeusean geratzen zirela ikusi zuen; literarioki ez zuen arrakastarik izan, eta ideologikoki bazterreko figura izateari ez zion utziko: nabarmena da, era berean, bizitzaren azken urte haietan hartu behar izan zuen jarrera guztiz diskretoa, inguru klerikalaren gainbegiratzea eta arbuioa saihestu ahal izateko.

\subsubsection{Euskal Herriaren iruditeria}

Pío Barojaren hautazko Euskal Herria da Jean Etxeparek Beribilezeko bidaian marrazten duen bera (Placer, 1958, 191. or.), hots, XX. mendearen lehen erdian idazleok idazkietan islatu zuten Euskal Herria da lurralde heze ez hiritarra, geografiaren erdigunea besarkatzen duena.

Agian, komenigarria da Arturo Campión-en (1854-1937) Pedro Mari kontakizuna aipatzea, kontura gaitezen Barojarena bezalako iruditeria dekadenteak nolako gauzapena zuen gaztelerazko beste idazki batzuetan ere:

En Pedro Mari, realizada en 1895, nos encontramos con una imagen decadente del pueblo vasco, que se ve arrinconado en sus límites geográficos, en su cultura y sus valores humanos. A su vez, se articula a ambos lados de los Pirineos unas estructuras estatales que coartan su autonomía ancestral.

Se defienden los valores tradicionales de una comunidad católica y rural dotada en su propia lengua e instituciones, pero esta composición estética posee una capacidad 
ideológica acentuada. Una faceta que comprobaremos al describir la readaptación que se ha de hacer de esta novela histórica, edificada sobre un pensamiento fuerista situado en su clímax de mayor intuición (López Antón, 1998, 178. or.).

Motibo berak erabil ditzakete beren iruditerietan bi idazleok: kontrabandoaren motiboa idazle bietan dago; pilotarien ospea ere bada bietan. Zalacaín abenturazalea pilotari jaioa da; pilota partidak deskribatzen dituzte hala Pío Barojak nola Jean Etxeparek. Aldiz, Pío Barojak gertakari militar edo ekintza zirraragarriak jaso ditzakeen lekuan, Jean Etxepare gehiago ikusten da nekazal ekonomiako zerez mintzo mugaren inguruetan dabilela, zibilagoa baita, ahaztu gabe 14ko gerran ibilia zela, eta gudari ohien bilkuretan hizlaria izan zela, baina ez da horren arrasto pertsonalik Etxepareren literatur lan bietan.

Pío Barojaren idazkietan euskal zertzeladek garrantzi handia hartu zuten (Sánchez Granjel, 1953a eta b; Plazer, 1968). Nabarmentzekoak dira, kontakizunen arloan, Vidas sombrías $(1900 ; 2010)$ ipuin-bilduma, Tierra vasca trilogia, La leyenda de Jaun de Alzate eleberria, El cura de Monleón eleberria, behinenak ez aipatzearren; gainera, itsasoari buruzko eleberrietan ere present dago euskaltasuna, eta, apur bat, leku guztietan. Saiakeraren arloan ere jorratu zuen euskal gaia.

Garrantzitsua da herri baten literatur iruditeriak aztertzean, zer nolako estereotipo identitarioak jasotzen dituzten idazleek lanetan. Estereotipo hauek izan daitezke kontaktuan dauden herrien artean sorturikoak, ala herriaren barneko estereotipoak. Bi idazle hauek estereotipoak desestaltzen saiatuko dira, eta sakonagoko ezagutza baten bila abiatuko, estereotipatuaren ezagutza sakonagoaren eta doiagoaren atzetik.

Euskarazko kritikan euskaldunaren irudiari erreparatu izan zaio, sarri Pierre Lotiren Ramuntchoren (1897) harira; izan ere, eleberriak arrasto luzea utzi du Euskal Herrian, hala euskaldunen nola erdaldunen artean: datorren atalean, kezka horien jarraipena egingo da euskaldunaren irudiari buruz (Casenave, 2003; Altonaga, 2006, 14-15. or.). Atal honetan tarte bat hartuko da demostratzeko herri-estereotipoen kritikak baduela lekua Pío Barojaren lanean ez ezik, Jean Etxepareren lanean ere, adibidez, Ganix euskal laborariaren figura erreibindikatzen duela Eskualtzaleen Biltzarreko burulehena zela (Charritton, 1984, 83. or.); edo beste hura, zeinetan frantximantaren figura salatuta frantsesaren izen ona aldezten duen Loiolako ostatuan, Beribilezeko auto-ibilaldian kontatzen duenez. Bi autoreok ziren Argien aldekoak, eta biok desestali nahi dituzte estereotipo sinplifikatzaileak, eragin kaltegarrikoak pertsona estereotipatuarentzat, dudarik gabe.

Barojak gertutik ezagutu zuen Euskal Herriaren iruditerian, azpimarratzekoa izan daiteke nabarmentzea nola desestali nahi izan zuen euskal landa-gizartearen barneko estereotipo latz bat.

Pío Barojaren Vidas sombrías $(1900 ; 2010)$ ipuin-bilduman ezaguna egin da «Mari Beltxa» izenburukoa, beraren orrialde ederrenetakoen antologietan jarri ohi dena, maitasun samurraren adierazgarria. Testuinguruan kokatzearren, kontuan izan dezagun Baroja deskribatzen ari dela Zestoan ezagutu zituen giroa eta pertsonaiak, mediku-lanean bertan egon zenean, estudioak amaitu eta handik gutxira, urte batez gutxi gorabehera. 
Ikusten dugu Baroja landa-inguruko estereotipoak porroskatzen sotilki. Mari Beltxa, adibidez, landa-gizartean baztertutako pertsona da, estereotipo baztertzaile baten ondorioz. Pertsonaiaren izena adierazgarria da: beltz-koloreak konnotazio kezkagarriak ditu. Orotariko euskal hiztegian honela dio: «beltz (V-gip, L, BN, S), baltz (A Apend). Ref.: A; Elexp Berg. Triste, aciago, desgraciado; penoso, duro, crudo. "Triste" A. "Baltz, terrible"». Berez, hiztegian ez dirudi kalifikatiboa gizakiei egokitu zaienik, hiztegiko adibideei erreparatuta; hala ere, badirudi Barojak herri usadioko konnotazio hori jaso nahi izan zuela. Hari horretatik, gogoratu daiteke oraintsu musikatutako Bizkaiko kopla zahar hura, emakume bat mintzo dela: «baltza naizela dineube (bis), ardoa be baltza da baina, danak edaten deube».

Mari Beltxaren ipuinean ere (Baroja, 2007), beltza kolore markatua da. Hona aipu batzuk hipotesiaren alde:

- «Mari Beltxa deitzen dizute, Mari Beltxa, Errege egunez jaio zinelako, ez beste ezergatik; Mari Beltxa deitzen dizute, eta bildots txikiak garbitegitik irtetean bezalaxe zara zuri, eta udako garitza bezalaxe hori» (33. or.).

- «Horren ederra zara! Eguzkiak aurpegia belztu omen dizu; zure bular aldea laua omen da; egia izango da agian; zure begi lasaiek udazkeneko egunsentiak dirudite ordea, eta zure ezpainek galsoro beilegietako mitxoletei hartu die kolorea» (34. or.).

- «Mainak zituen umeak, zuk, bera alaitzeko, behiak erakusten zenizkion, Gorriya eta Beltza (...) Gero bestearengana joaten zinen, eta, hatza harengana luzaturik, esaten zenuen: «Hauxe dugu Beltza... zein beltza..., zein gaiztoa... Hau ez dugu maite. Gorriya, bai» (35 or.).

Nabari da Mari Beltxa estigmatizatuta dagoela (omen, agian partikula modalen agerraldiak). Errepikakorra da koloreen arteko dialektika, euskal usario hartan zuria, horia eta gorria positibotzat jotzen direla, eta beltza, aldiz, negatibotzat. Esanguratsua da excusatio non petita, acusatio manifesta delako irizpidea ere aplikatu daitekeela lehen aipuan («Mari Beltxa, Errege egunez jaio zinelako, ez beste ezergatik»). Badirudi beltz kalifikatiboaren esangura negatiboa ez zaiola eskapatzen inguru errurala ezagutu duenari ${ }^{2}$. Pío Baroja, 30 urte ez zituen medikuzar (34. or.) gaztea, estereotipoa apurtzera dator, guztiz kontrako ikuspegia ematen duela.

Jean Etxepare ere gizarteko higiene pedagogiko baten atzetik saiatu zen desestaltzen bere begietan zuzenak ez ziren estereotipo batzuk. Bi adibide identitario jartzearren, hemen aipatuko ditugu euskal laborariarena eta turista frantsesarena.

Laborari apalaren aldeko apustua egiten du Etxeparek, haren lepotik barre egiten duten kanpotarren kontra. Gorago esan den bezala, Jean Etxepare ere ibilia da 
estereotipoen kontrako lehian: hautsi nahi izan ditu ez bakarrik Ganix euskal laborari gutxietsi eta trufatuaren hura, baita frantximantarena ere, beste estereotipo identitario bat aipatzearren, alegia, frantses euskaldunek arbuiatua. Beribilezen Jean Etxeparek laborariaren defentsa egiten du, bisitari frantses batzuen kontra. Aldiz, frantsesaren apologia egiten du han ere, voltairianoek euskal iruditerian izan dezaketen konnotazio gutxiesleen gainetik.

Ganix laborariaren kasuan, ohikoa zen Euskaltzaleen Biltzarreko kideen artean, Etxepare barne, euskal laborariaren irudia duintzeko ahalegina: Leon (Charritton, 1984, 83. or.), Dominique Dufau (Dufau, 1950a; 1950b). Hona orduko testuinguru historikoa:

Gogoratu dezagun turistak trumilka ari zirela zabaltzen Iparraldean sasoi horretan. Horrez gain, Ameriketara joaleak ere ez ziren gutxi, ahultzen ari baitzen nekazari-estamentua. Kontserbatzaileak gainbehera gelditzen saiatzen ziren. Euskalduntasuna eta euskara bera ere aldaketaren kontrako txerto eta hesiak ziren. «Buru argituek» kezka zuten euskaldunek arima galduko ote zuten ingurumena aldatuta, dela frantsestearekin dela Ameriketako tentaldiekin, emigratu egiten bazuten. Euskal gizartean, behinik behin, gizakiaren ongizate morala bermatzen zuen Elizak (Ortiz de Pinedo, 2011, 96. or.).

Jardunbide hori koka daiteke, bestalde, euskal eliteek Pariseko elite zentralistaren kontra hartu zuten bidean, boterea (kulturala, kasu honetan) eskuratu nahiz herrialde hurbileko jendartearen alde eginez XX. mendearen lehen herenean. Aztertuta dago ahalegin dezentralizatzaile horren alderdi kulturala, jadanik.

Egiatan, hala Frantzian nola Espainian bada mugimendu lokalista bat tokiko ezaugarriei gora eman nahi diona garai hartan. Frantzian, hainbat "sociétés savantes» sortu ziren helburu horrekin, Iparraldean ezagutu zirenen antzekoak (Gasnier, 1984-1992, 3464. or. eta hh.). Etxepareren bizialdian ugaritu egin ziren nabarmen: 1862an 204 zirenak, 1921ean 915 ziren (Gasnier, 1984-1992, 3436. or. eta hh.). Euskal Herrian ere XX. mende hasierakoak dira Euskaltzaleen Biltzarra, Eusko Ikaskuntza, Euskaltzaindia... gure artean ezagunenak baino ez aipatzearren.

Frantziaren homogeneizazio-prozesuan nahita ez sortu ziran gatazka identitarioak komunitate txikiagoen artean, elkarrekiko estereotipoetan islatuak; istiluak sortu ziren, aldi berean, kontaktua eta bereizketa zekartzan muga identitarioaren bi aldeetatik. Ganix laborari euskalduna denaz bezanbatean, nunbaitik jinikako jaunxkila batzuek egiten diote bisita lehenik; geroago, euskaltzaleek bigarren bat, honela deskribatzen baitu Jean Etxeparek:

Gure bidaiarien harritzia! Etzien Ganixek den gutieneko eiterik, errana zakoten gizon bitxi harekin, ez bere jauntzian, ez ibileran, ez bere solasetan ere. Erdeinuz eta trufaz nunbaitik jinikako jaunxkila batzuek beren aho mihietan zerabilaten laborari puska on bat, ez batere zozoa haatik, ez herabea ere, horra nola agertu zitzakon Léoni, Ganix egiazkoa. Jostagailutzat tonto zaukaten eta eskoil, haizu den baino gehiago, aipatu arrotz xirtxilek, adiaraziz gainera, edo bederen geroago barnago beren gogoari emanez, haren iduriko zitazkela euskaldun guziak (...). 
Euskalduna agertzeko on da non nahi: gizonez gizon ez du inoren ahalgerik. Neurri batetik goiti, badaki behar ordian irrien sar-arazten. Ez beti mihi eta makil ukaldika, ez bainan batzuetan, eta askok uste duten baino ardurago ere, bere gizontasuna lañoki erakutsiz (Charriton, 1984, 83. or.) ${ }^{3}$.

Ganixen ironiak desmuntatuko du bisitarien buruaskitasuna, apur bat Sokratesek edonor aporiaren mugetara bultzatzen zuen bezala aurrean jartzen zitzaiola, jakituriaren hastapeneko prozedura posible bakarra (Jankélévitch, 1964)4. Izan ere, esanguratsua da Jean Etxeparek proposatzen duen euskaldunaren erantzun graduatua irriaren bitartez, kanpotarren erdeinuaren aurrean. 1923ko Etxepareren testuan, ironiaren erabilera da erresistentzia-seinalea bortizkeriaren gainetik, hirugarren espazio bati irekiera ematen diona (Ury, 1999; Fernández, 2006, 217-260. or.), hau da, kanpotar/bertoko oposizioari gaineratzen diona paradoxaren eremua, zeinean bertokotasuna balio erantsi gisa eraikitzen den diskurtsoan (Delvaux \& Caron, 2010, 602. or.).

Beraz, Etxeparek eta Leonek proposatzen dute estereotipoa gainditzeko bidea, euskaldun estereotipatuaren ezagutza hurbilagoa proposatuta, ezagutza hurbila baita estereotipo makurrak gainditzeko biderik onena (Stangor, 1995; Rogers \& Aronson, 2013). Harreman blokeatu baten adierazgarria da estereotipoak erabiltzea bi komunitateren artean. XX. mendearen hasieran oztopo hori bazegoen; Jean Etxeparek ulerkera mentalki higienikoagoa proposatzen du estereotipoen gainetik, hala euskaldunak ulertzeko nola frantsesak ulertzeko. Izan ere, borrokatzen ditu frantsesen eretzera inguruan somatzen zituen estereotipo arbuiatzaileak ere, Beribilezen bertan.

Ziur aski, zer esanik izango zuen Iparraldeko giroak frantsesak gaingiroki mesfidantzaz begiratzen baziren, areago erlijioaren inguruko kontuez mintzatu badira askatasun gehiegiz, batzuen ustez.

Beribilezeko bidaiariak joan dira Loiolako ostatura, santutegia bisitatu ondoren. Han, frantses bitxi bat mintzatu zaie ausarki samar frantximanta, jesuitekin kritiko eta kexu haien jabetzapeko ostatu-zerbitzuaz (Etchepare, 1931, 69. or. eta hh.); erantzunez, medikuaren lagun batek frantsesaren figura kritikatuko du bere txandan. Frantximantaren estereotipoaren bitartez plazaratzen da Beribilezen identitatearen auzia, elkarren ondoan jarrita euskalduna eta frantsesa.

Etxepareren prozedura da estereotipoak jasotzea paperean, segidan ikuspegi orekatuak proposatzeko irakurleari. Bi kasuetan, idazlea bere garaiko gizartean zabal zebiltzan estereotipo bi horiek zuzentzera dator, alegia, jesuiten aldera errespetua eskatzera dator, eta frantsesaren figura kaskarra duintzera beraren izen ona berrezarriz.

3 Jean Etxepare (1923). «Baigorriko bilkuran buruzagilehenaren mintzaldia», «Ixtudianteen primak» sarietarik bat Leon Leonen kontakizunari ematean.

4 «Le mouvement de la conscience ironique» atalaren sarrera. 
Etxeparek autura dakartza gizartean kontrakarrean zeuden jesuitak eta frantsesak, Voltaireren jarraitzaletzat hartuak, iritzi komunari men eginez. Hona frantximantaren komentarioa Etxepareri, Ignazioren etxean kanoi txiki bat ikusten dutenean bisitan; nabaria da jesuitei egozten zaien politika klasista:

Hainbertzenarekin, ene aldeko ikusliar baten [frantximantaren] hitz hauiek jotzen dautate beharria frantsesez:

-Ehun debruak berekin dituzte Jesuistek. Bazterretan dituzten komentu guziak holaxe zainduak dauzkate, beherean kanoiez, gainean aldiz mitrallusez. Orroaz jauzi baledi egun edo bihar jende xehea, baluzke hemen azpitik odoletan idukitzeko gupida ez litzaizkiokenak!

-Ori, diot ihardesten mintzai berean, izan bedi norbait iharduk lezokena: oilo batzu bezala iziturik lasterka bailoazke ihes, jende handien hogoietarik hemeretziak! (Etchepare, 1931, 58-59. or.).

Ez bakarrik klasistak, jesuitak diru-zaleak ere badira:

-Hau da, hau egiazki Jesuisten kafea! dio bazterretik frantses harroak. Nahi dituzten sos guziak biltzen beren museoa erakutsiz, horma puska baten kraskatzeko aldiz mailuxkarik ere ez! Sakelak bethe ondoan, arrats guziez sorhopil huntan, gehiagoko deusen axolarik gabe, diren bezalakoek egiten ahal dituzten jauzi-putinkak! Madarikatuen gatik, egarriarekin hiltzea luke hemen gizonak (Etchepare, 1931, 70. or.)

Turista frantses hori bera tabernan topako dute geroxeago bidaiariek; kexu da Loiolako ostatuan jasotzen ari den zerbitzu berankorraz. Jean Etxepareri frantximantak Voltaire dakarkio gogora ( Ez dakit zer bidez, Voltaire zenaren orhoitzapena heldu zait gogora. Haren ilobasoetarik bat ditake gure auzoa» (Etchepare, 1931, 71. or.).

Animalia baten traza hartzen du frantximantak narratzailearen hitzetan:

Bere ezin-egonaz urtxintxa bat zirudiela baikinion oixtian, orai mathel, begi, esku eta zangoen igitzetik ximinoa dirudi (Etchepare, 1931, 72. or.).

Azkenik, zerbitzariak ekarritako edariaren eraginez, «Voltaireren ilobasoa elizako saindu bat bezain geldi dago eta ixil, orai, bere kaderan (...) Ihizi on baten aurpegia daukalarik, etzait iduri halako gizon gaixtoa dela» (Etchepare, 1931, 72. or.). Bestalde, da jendetasunik gabea, narratzailearen ustez, gaizki esaka baitabil zuzen kontra.

Hala jesuitak, nola frantsesak eskematizatuak daude, erridikuloski deskribatuak. Turista frantsesak eta Etxepareren lagunak baliatzen dute eskema soila, animalizazioa, estereotipatuen iritzien deuseza azpimarratzeko. Henri Bergson-ek Le rire (1900) liburuan aipatu zuen irria gizakien portaerei mekanika-itxura ematetik sortzen zela; Etxeparek Bergson irakurria zuen patxada nahikoaz, nahiz ez dakigun liburu hori ere irakurria zuen.

96 Fontes Linguae Vasconum (FLV), 125, enero-junio, 2018, 85-112

ISSN: 0046-435X ISSN-e: 2530-5832 
Pentsa liteke frantximantak Kanboko bidaiariei zuzentzen dien berbaldiaren mamia jesuitei buruz barra-barra zebiltzan topiko antiklerikalen oihartzuna dela.

Zehatzago esatearren, jesuitek, Lagundiaren ibilbide historikoan, aurkitu dituzte aurkari famatuak Frantzian, eta bestetan ere bai, bide batez esanda: Frantzian, nagusiki Pascal, Nicole, Voltaire, Michelet eta Quinet. Pertsonaia historiko horiek irudikatzen dute erlijioaren eta kulturaren arteko talka. Adibidez, Pascal jansenistaren ustez jesuitak laxistak dira oraindik ere maiz berrargitaratzen den Les Provinciales (1700) liburu klasikoan dioenez, hau da, pekatuak kudeatzean kasuistika baliatzen dute, beren eragina zabaltzeko politikaren eta boterearen gizarte-esparruetan. Pascalen ustez, jesuitak, pekatuaren penitentziak ipintzean, eskuzabalegiak ziren penitentziarekin, kasuan kasuko zirkunstantziek arau orokorrak baztertzea zilegi egiten zutelako. Bestetik, jesuitei egotzi zaie luzaro klase boteretsuen aliatuak izatea.

Jesuitak, bestalde, ultramontanoak izatea gertatu da, hau da, klerikalak, Elizaren edozein zaharberritzeren kontrakoak, gizartean burgesiaren botere sekularizatzailea hedatzen ari zen memento hartan. Aurrekarien atalean aipatu denez, Etxepare bera klerikalismoaren aurkari agertzen zen, baina soilik Lacombe lagunari eginiko gutun pribatu batean, 1905eko ekainaren bian (Xarriton, 1995). Jesuiten ultramontanismoak bat egingo zuen Espainian alderdi integristarekin, katolikoetan muturrekoena. Beraz, Beribilez da jesuitei buruzko sentimendu gutxi asko topikoen erakusleihoa. Pío Baroja Etxepareren garaikideak ere antzeko aburuak jaulki zituen 1898n (Baroja, $2000)^{5}$.

Alabaina, helduaroko bere filosofia patxadatsuari men eginez, Beribilezeko Etxeparek modulatu egiten du jesuiten aurkako iritzi kritikoaren zurruna, baina ez du baztertu nahi haren aipatzea, koherentea izan nahian bere egiaren bilaketa karakteristiko harekiko: modulazio hori bera ageri baita Beribilez bertako beste pasarte batzuetan ere. Etxeparek jesuiten aldeko eta kontrako iritziak jasotzen ditu: aldekoak narratzailearen ahotsean, eta, kontrakoak, frantximantaren bidez, narratzailearen eta irakurlearen bitartean jarritako pertsonaiaren bidez, kasu honetan.

Etxepare zorrotz agertzen da ziri antijesuiten kontra:

Jesuisten erakaspenari edo sinesteer berer sistako baten emaitera loake segur bere mihi ozpinduaz [frantximanta], -bihotzean min egiten duten, eta sekula nehori-buruz igortzeko ez litazken sistako hetarik (Etchepare, 1931, 71. or.).

Nolanahi ere, antiklerikala da Loiolan topatutako frantses hau, nahiz eta baziren frantses zuriak ere: Eskualduna aldizkari arrakastatsua, esaterako, Action française eskuindarrarekin lerratu zen Gerra Handian (Bidegain, 2013). 
Kanpokoaren estereotipoak balio dezake talde-kohesioa lortzeko, eta frantximantaren kasu honetan frantses gaizki esalearen estereotipo honek duen balioa izan daiteke euskaldun fededunen taldeko kohesioa areagotzea, eta, horregatik, ohiko estereotipo errepikatua izatera iristea orduan (Schröder-Abé \& Schütz, 2013, 155. or.).

Jean Etxepare zubigilea zen bi gizarteren artean: euskalduna eta frantsesa. Bi gizarteen arteko elkar ezin ulertuak gainditzen saiatu zen, besteak beste, elkarren arteko ulermena oztopatu zitzaketen estereotipoak gudukatuz. Hegoaldeko gizartea ere nahi zuen hurbildu Iparraldeko kulturara, hurbilagotik ezagututa eta haren izaeraren berria emanez.

Beribilezen badira estereotipoak frantsesei buruz. Estereotipoak dira baliabide ekonomikoa gizarteak erabiltzen duena, Bestea edo kanpokoa azkar batean karakterizatzeko; gertatzen dena da estereotipo horiek elkar ez ezagutzearen ondorioa direla, uniformizatu egiten baitu Bestearen ikuspegia prozedura sinpletzaile batez. Arazoa larriagoa izan daiteke estereotipoa negatiboa denean, eta komunitateen arteko harreman toxikoa sortzen duenean. Iparraldean bazen gogo-egoera bat, Frantziako kulturarekin areago bat egiteak ekar zitzakeen ondorioez kezkatua.

Jean Etxepare jardun zen gauzak era arrazionalago batez ulertarazten irakurleari, bi komunitateen arteko ezinikusiak gainditzen saiatu zelako. Frantses-izaeraren alderdi positiboak azpimarratzen ditu, batetik. Beste alde batetik, euskaldun laborariaren gainean kanpotarrek izan dezaketen ikuspegi iraingarriari ere buelta ematen saiatzen da. Laborariak badu duintasun errespetatu beharrekoa Euskal Herrian, nahiz eta bisitari frantses arruntek jakin ez hura estimatzen.

Hori da, laburbilduz, Baroja eta Etxepare idazleek hartu duten eginbidea: gizartean dauden molde sinplistei aurre egitea, eta sakonagoko hurbilketa egitea estereotipo gaitzesgarriak salatzeko, modu sotilean baino ez bada ere. Iruditzen zaizkigu horiek gizarte tradizionalaren eta ez hain tradizionalaren ilunguneak argitzeko biek egiten duten saioa, estereotipo herrikoi batzuen errazkeria klasifikatzailea arteztu nahiz, arrazoiaren eta aurrerakuntzaren baitako ideia ongile batzuei men eginez.

\subsection{Aldeak}

Bi idazleen biografiei buruz, azpimarra daitezke profesionalki izan zituzten bizimodu diferenteak. Etxeparek medikuntzari ekin zion bitartean, tarteka idazketa lantzen zuela baina arrakasta editorialik gabe, Barojak idazletza zuen lanbide eta horrenbesteko arrakasta komertziala lortu zuen non argitaratzetik bakarrik bizi zitekeen.

\subsubsection{Paisaia idazten}

Idazle bakoitzaren paisaia marrazteko moduak erakuts dezake argiki zein den beraren pentsaera. Honako honetan fokua jarriko dugu paisaia horren bi alderditan: itsasoa eta lehorra. Lehenengo eta behin ekingo zaio inguruko itsasoen gainean idazleok ehundu dituzten alegiazko interpretazioak jasotzera. 
Jean Etxepare helduak Mediterraneo itsasoaren abaroa hautatzen du, Ameriketako itsasoa bazterrean utzita; Ameriketako itsasoa litzateke Beribilezen gaztetako karraren sinboloa, sasoi bat non idazleak askoz kar handiagoa zuen iritzi disidenteak plazaratzeko idazkien bitartez. Datozen pasarteetan, jorratuko ditugu Etxeparek liburu horretan agertu zituen burubideak hil baino urte gutxi batzuk lehenago, hain zuzen, «Itsasoa kukulauka»X. atalean.

Pío Barojak ere konparatu ditu Mediterraneoa eta Atlantikoa. Donostiarrak ez zuen askorik prezatzen kultura klasiko Mediterraneoak sinbolizatua. Nahiago zituen Atlantikoa eta iparraldeko herriak, germaniarrak, besteak beste, herrialde latindarrek ez baitzuten idazlea bereziki asetzen, herri bakoitzaren nortasun bereziei erreparatuta (Lorenzo Arza, 2017). Aipu luzea barkatuko ahal zaigu, baina pasartea askoz luzeagoa da, eta zinez irakurgarria, gure ustez:

El Mediterráneo es paz y armonía; el Atlántico lucha y contradicción. El Atlántico tiene una mitología hórrida, resto de la época e que el mar era un gran peligro: el pulpo del Maelstrom, las arañas de los Kraken, la isla del Fuego con sus piratas; el Mediterráneo tiene una mitología más clara y más solemne, sirenas, ninfas, delfines, y otros seres fantásticos dirigidos por el tridente de Poseidon.

El Mediterráneo es Oriente, Eneas y Palinuro, la leyenda del vellocino y el gorro colorado; el Altántico es el caos, los vascos pescadores de ballenas, los wikings, los normandos conquistadores, y, al mismo tiempo, la Atlántida y el Jardín de las Hespérides; el Atlántico es la alta piratería, los grandes naufragios, el bergantín negrero, el marino con un anillo en la oreja y una cacatúa en el hombro.

El Mediterráneo es un mar clásico y, al mismo tiempo, realista; el Atlántico es un mar romántico y turbulento (Baroja, 1920, 183. or.).

Irakur daiteke Beribilezen (Etxepare, 1931, 81. or.) idazleak nola hobesten duen Mediterraneoa, argi geratzen dela, bi itsasoak interpretatzean, bi idazleek interpretazio berdintsua egiten dutela. Desberdintasuna, hori bai, bakoitzaren hautuan dator, areago Jean Etxepare helduak 1931ko Beribilezen adierazitakoari bagagozkio bizitzaren azken urteetan bihotzetik gaixo zegoela, oker ez bagaude. Funtsean bat gatoz Kepa Altonagarekin medikuaren azken urteetako ikuspegi etsia gogoan duenean (Altonaga, 2006, 239-240. or.), Jean Etxepareren bihotz eroriko hitzak interpretatzean (Charritton, 1984, 366. or.).

Argudiaketa gehiegi behartu gabe, baiezta liteke Atlantikoak sinbolizatzen duen ekintza-zaletasuna, Nietzscheren botere-grinaren beste gauzapen bat dela, behinik behin, bat datorrela berarekin: supergizakia, kasu honetan, Barojaren euskal itsas-gizonetan hezurmamitua. Esan behar da, Barojaren aipuko liburu hori, Memorias de un hombre de acción sailaren VI. liburukia dela, izenburu adierazgarrikoa. Aztertua da Friedrich Nietzscheren itzal luzea Espainiako eta Frantziako letretan (Sobejano, 2004; Le Rider, 1999; Pinto, 1995); oraindik ere, Nietzscheren auziak zabalik dirau (Boyer et al., 1991). 
Jean Etxepareren kasuan itsasoen alegiak dira, aldiz, Nietzsche gaztetan irakurri izanaren errebisio bat, Mediterraneoa hobesten baitu, Ameriketako itsasoaren nostalgia-izpi batekin bada ere. Bidenabar esanda, Nietzschek Etxepare baitan eta haren obran izandako pisuaz aipuak badira euskaraz, baina nahiko gai zehatzetara mugatuak (Kintana, 2001), gainerakoan, iradokizun interesgarririk badirela ukatu gabe inola ere, bereziki Nietzscheren interpretazio eskandalu-sortzailearen, primarioaren, harira (Altonaga, 2006, 59, 77-81, 83-84. or.); ziur aski, mereziko luke finkatzea filosofo alemanak Iparraldeko medikuaren lanetan utzitako eraginaren alderdi gehiago, nahiz eta eraginak zehaztea zein konplexua zaion literatura konparatuari ezaguna izan (Guillén, 2005, 72-74, 283. or.), esate baterako, Etxeparek egiari buruz zuen ikuspegia, medikuaren idearioan koska munta handikoa (Heit, 2012, 521-523), besteak beste, Buruxkakeko (1910) «Egiaren hiru itxurak» atalean islatua, gure ustez; Nietzsche hori eta gehiago ere bada inguru honetan, alemanak duen gaur egun pili-pilean dauden segidako pentsalariei hurbilagotik erreparatuz gero bakarrik (Heidegger, Bataille, Artaud, Derrida, Foucault...), edota, Euskal Herrian, Salaberria, Maeztu, etab., Espainiakoak aipatu gabe. Ez alferrik, Etxepare eta Mirande aipatzen dira euskal literaturari modernitatearen ateak ireki dizkioten bi idazle buruzagi gisa literatur kritikan (Kintana, 2001, 119-123. or.).

Etxepare Gipuzkoako kostaldean zehar dabilela Beribilezen ematen digun itsasoen alegietan sakonduta, Ameriketako itsasoaren ikuskizuna itxuraldatzen duen alegorian, Ameriketako itsasoaren gaineko hodeiak lirateke irudikatutako hiriak, alegia, Jean Etxepare gaztea liluratu duten pentsamenduaren iduriak, irakurle jakin-gosea ibilaraziak gero eta urrunago beti, sosegurik gabe eta artega.

Badirudi Jean Etxeparek ekimen-gogo hiritar eta, aldi berean, burges horretan atzera egiten duela helduaroan Mediterraneoa hobetsiz Ameriketako itsasoaren kaltean, hein batean ekimen iraultzailea baitzen gaztetakoa, idazleak sinboloen bitartez adierazten duen bezala. Kontuan izan XIX. eta XX. mendeetako hamarkada haiek burgesia gailentzearen eta Europako kolonialismoaren urteak zirela (Kinder et al., 2007).

Beste alde batetik, Beribilezen Ameriketako itsasoak autoko beste euskaldunei oroitzapen kutunak dakarzkie, seguruenez migrazio jendetsuen ildotik:

-Xuxen mintzo zira. Abantail horiek ez ditut ukatzen. Aithortuko dut Mediterranea osoki karana zaitala. Lehen ikus-aldian berean bildu ninduen.

Ez dakit zendako maiteago dutan, halere, Ameriketarako itsasoa. Odolean dut hau; gogoratzeak berak harrotzen dauzkit zainak.

Eta zuri, ameslaria [Etxepare], zer zaizu? (Etchepare, 1931, 81. or.).

Guztiarekin ere, gaztetako gehiegikeriaren ostean, idazleak neurria hobesten du Greziako sophrosyne kontzeptuaren bertsio sinbolikoan emana, alegia, Partenonen ordezko iruditzat ematen digun usoaren figuran: aspaldiko neurrigabekeriaren lekuan, usoaren bermea. Europako burgesia bera ere noraezean zebilen Lehen Mundu Gerrako 
zafraldiaren ondoren, Belle Époqueko arinkeria-giroan murgildua, Donostia bezalako hirietan, adibidez (Etchepare, 1931, 84-90. or.).

Greziaren aipamena, ordea, izan zitekeen konplizitate-keinu bat irakurlego frantsesarekiko, denok partekatzen dugun leku komuna baita Grezia kulturaren ama delako topikoa, eta Jean Etxeparek bakezkoak egin nahi hartzaile errealen gehiengo batekin, gogoa zeru-alde airatze (Etchepare, 1931, 84. or.) gehiegizkoaren kontrapisu gisa, Jon Casenavek baloratu duen bezala, Jon Etxepareren ezagule hurbila, elkarrizketa batean; zer nola miresten zuen Grezia ezin jakin zehatz.

Itsasoen alegiak aztertu ditugu Beribilezen, liburu horri buruzko tesiaren atal batean, eta leku faltan hemen ezin dugu luzazago jardun.

Itsasoen interpretazioaren ostean, ekin diezaiogun bi idazle hauek landa-lurrak nola irudikatzen zituzten erreparatzeari: zeinek bere landako ikusmoldea zuen, baina beti ere hiriarekiko urruntasun batekin. Erruralismoa ohiko gertakaria da azken modernitatean, industrialismoaren itsusitasunari eta uniformizazioari balio berriak kontrajarrita, Georg Simmel soziologoak ondo dioenez, XX. mende hasierako Berlinez ari dela (Simmel, 1903).

Este canon anti civilizatorio se concentra sobre las ciudades en contraposición al campo como fuente de virtudes morales y físicas. Pío Baroja lo recoge como un rasgo inherente al vasco en sus Fantasías vascas (1941): «Yo siento un profundo desdén por la vida de las ciudades, por todas esas cosas que constituyen lo que se llama civilización» (Lorenzo Arza, 2017, 7. or.).

Pío Baroja ez dago ados ezta Donostia hiriak XX.mende hasieran zeukan izaerarekin ere, ezaguna den bezala, jaiotzaz donostiarra izanagatik (Baroja, 1917, VIII kap.; Baroja, 2006, 16-17. or.).

Gizarte modernoak ez du eskaintzen taldearen babesa, tradizioko gizartean bezala. Pío Baroja bera ere aspertu egin zen Madrilen bizitzeaz, orduz gero Berako Itzean pasatzen zuela urtearen erdia, edozein irriki eta gizarteko goranahitik urrun:

Este puñado de jornaleros de la Vera del Bidasoa (comarca limítrofe entre Francia y España) guardan esa «savia natural» del pueblo español que se ha diluido en la mentalidad gregaria de las ciudades: «La gente de hoy, alejada de la naturaleza y de los anillos nasales, vive en el artificio de una armonía moral» (César o nada 572). El escritor vasco encuentra en la Naturaleza las raíces genuinas de un carácter español que poco tiene que ver con la oratoria histriónica de los hombres de ciudad (Lorenzo Arza, 2017, 7. or.).

Hiri modernoak dirua eta abstrakzioa jartzen du, gizarte erruralak harreman emozionalak eta hurbiltasuna jartzen zituen tokian. Diruak uniformizazioa dakar, eta indibidualtasunik ezin du onartu. Jean Etxepare kexu zen honetaz Donostiatik igarotzean 1929an. Gaur egun ere talde-nortasunak gora datoz, uniformizazioaren aurrean: penintsulako ezinegon identitarioa ezaguna da, baina, adibidez, AEBn ere hispanoek, 
beltzek, indiarrek ere beren ezagutza zabala eskatzen dute. Badira, gainera, hainbat eskola eta bolada: Zena, punka, makrobiotika, trikitixa, bertsolaritza, euskal dantzak eta kantak, veganismoa, Pokemon eta beste hainbat. Friedrich Nietzsche bi idazleon irakurgaia zegoen garai bateko metropoli uniformizatzailearen kontra, eta indibidualismoaren alde sutsuki (Niemeyer, 2012).

Pío Baroja plutokraziaren kontra dago, eta aristokraziaren kontra. Diruaren kontra dago eta klasismoaren kontra. Iruditzen zaio pribilegioak izateko, arrazoi bat argudiatu behar duela dagokion klaseak. Gaztetasuna, indarra, inteligentzia eta edertasuna ez datoz inongo klase bereziri eratxikiak (Bello Vázquez, 1990, 74. or.).

Un talante similar se aprecia en Baroja cuando borra los núcleos urbanos de sus descripciones del País Vasco: «Es casi seguro que Baroja creía que el País Vasco era la tierra, los prados, las montañas, el espacio geográfico de España y Francia, y que Bilbao era una cosa aparte» (Maraña 3). El capitalismo de las ciudades corrompe el vigor de esos campesinos a los que identifica como estirpe de «hombres vitales». Sus Vidas sombrías (1900) compilan historias de jornaleros, pescadores, que luchan a diario y que reniegan de las llamadas a quintas, las iglesias o las fábricas (Lorenzo Arza, 2007).

Aipatu da goratxoago gizarte hiritartuan jendeak nola bilatzen dituen nortasun bereziak, diruaren nagusigoari, uniformizazioari, giza harremanen banalizazioari, abstrakzioari eta antzekoei aurre egiteko. Pío Barojak euskaltasunaren testuinguruan bultzatu duen paganismoa nortasun berezi nahi horren isla gisa interpreta liteke. Alde horretatik, Jaun de Alzate (1922) bezalako eleberriek hipostasiatu egiten dituzte herri-sinesteak, nortasun bereizgarri baten bila. Sineste kristauek uniformizatu egiten dute, unibertsala izan nahi baitu katolikotasunak. Erruralismoaren barnean paganismoak leku koherentea izan dezake, horren karietara. Horrez gain, Pío Barojak Jaun de Alzaten hurbildu egiten dizkie euskal sinesteak (Urtzi, lamiak, akelarreak, sorginak...) ipar Europako mitologiei, ez baita alferrik Urtzi-Thor jainkoaren izena liburuan, eta ez Jaungoikoa, ustez eta izaera latinoaren erakusgarria zela, Pío Barojak horrenbeste hastio baitzuen.

Tarteki gisa, aipa daiteke Jaun de Alzate kontakizuneko eite nietzschearra. Hala ere, Barojak Nietzscheren ildoko giro dionisiar paganoa sakonago jaso arren, Etxepare goiztiarragoa da alemanaren oihartzun hori jasotzerakoan (Kintana, 2001, 118. or.). Buruxkakeko (1910) «Amodioa» atal itxura batean nietzschearra lehenagokoa da Jaun de Alzate (1922) baino.

Ezin da ukatu, Etxepare ere erruralismo baten aldezlea dela, baina Barojarenaz bestelakoa: Etxepare erruralista da beraren interes-fokua landako errealitatean pausatzen delako nagusiki. Aldiz, askoz prosaikoagoa da Etxepareren ikuspegia Beribilezen; esaterako, kezkatzen du landa inguruneen emankortasun agrikola oroz gain. Kezkatzen dute, bestalde: etxeen eraikuntzaren nolakotasuna, ea kalitatezkoa ote den; landalanaren mekanizazio maila; azienda-traturako feria-antolakuntza nola hobetu, Ameriketako ereduei erreparatzen diela, arrazionalagoak direlakoan denboraren aldetik («Tratuak ordu batez» in: Buruxkak, idazlearen lehen liburua); errepideen zoruaren 
egoera, mugaranzko errepide berria zabaltzeak berarekin bat festa dakarkiola autozaleari; langileen bizitza-maila ekonomikoa eta lanaren gogortasuna; baserrietako nagusi eta morroiek jasotzen duten arreta eta haien egoitzen higienikotasuna egokia ote den («Eriaren gela» in: Buruxkak); nekazaritzako produkzio industrialaren antolakuntza («Lilien usaina» in: Buruxkak). Horrez gain, inplikatu egin zen Aldudeko udalean, herriaren aldeko zereginak burutzeko.

Badu enpatia berezia herrietako andreekiko, kasurako haien arteko loturak iraunarazi nahiz, iturri-lekua erdigunera aldatzea kritikatzean, garbitzaileen arteko konfidentzialtasun-giroa zapuztuko zelakoan («Ithurri lekua» in: Buruxkak). Andreen heziketa ere gogoan du («Igande arratsaldetan» in: Buruxkak).

Oroitzapen enpatikoak ere baditu landa eremuan izandako esperientziei buruz ( $« \mathrm{Ka}-$ ttin»; «Biritxiak»; Itze-egilearen txakurra» in: Buruxkak).

Horrek ez du kentzen heziketa morala ere partitu behar izatea bere bizikideak leziatuz: gehiegizko kar misiolari masokista kritikatzen du, martiri gurakoa nabarmen utzita («Misionestaren ezteiak» in: Buruxkak); debozio itxuraz mozorrotutako arinkeria ere bai ( «Sainduaren errangurak» in: Buruxkak); sineskeria eta basa medikuntza maiseatu beharrean aurkitzen da Bordeleko unibertsitateko doktorea.

Arras arduratua zegoen Eskualtzaleen Biltzarreko burulehen zela herri-kulturako agerkizun askoz: harri-langintza, menuisergoa; herri-antzerkiari ere duintasun minimoa eman nahi dio. Pilotarien gaixoez arduratzen da doktorego-tesian; euskal sukaldaritzaren eta ardo eta sagardoen jarraipen zehatza egiten du Beribilezen. Programa sozioekonomiko osoa da berarena.

Nolanahi ere, medikua jabetzen da zein latza izan daitekeen bere egoera, eta bakartia, «buru argitu» Aldude bezalako laborari-herri txiki batean bizi beharrez urtez urte (Altonaga, 2006, 155-157. or.), eta ez da itsua Bilbo batek, Bordele batek, edota baita Baiona batek ere eskain ditzaketen abantailez bizilagunentzat.

\subsubsection{Euskararen dilema}

Euskararen arloan, ikuspegi kontrajarriak zituzten. Pío Barojaren iritziz, euskarak ez zuen etorkizunik: sentimentalki baliosa izanik ere, kulturarako ez zuen balio. Jean Etxeparek, aldiz, borroka luzea egingo zuen bizitzan zehar euskara noranahikoa egiteko ahaleginean. Pío Barojak aurkitzen zion euskal ahozko literaturari nortasun-ukitu sentimental zehazkabea, euskal berezitasun baten adierazlea izan zitekeena, baina ez askoz gehiago (Baroja, 1919).

Pío Barojak euskarari buruz duen praktika da iraungitzera doan kultura baten testigantzak jasotzea, modernitatearen aurrerakuntza bere ustez geldigaitzaren aurrean. Horrelako lanak egin izan dira Frantzian ere, adibidez, izenburu adierazgarriko $\mathrm{La}$ fin des terroirs. La modernisation de la France rurale 1870-1914 liburuan bezala, non Antzinako Errejimenean indarrean zeuden usadioak jasotzen diren, itxura baten, Euskal Herrian etnografiak egin duen bidetik (Weber, 1983). Horretara, liburu frantsesak 
atal bat du, Pío Barojari hainbeste gustatzen zitzaizkion herri-literaturako laginei eskainia: kantak, esaera zaharrak, maskaradak... Pío Barojaren euskal giroko idazlanak zipriztinduta daude nonahi horrelako herri-jakintzako pitxiz. Resurrección María de Azkuek, gure mediku bi hauen garaikidea, antzeko bidea hartu zuen bere Euskalerriaren Yakintza (1935-1947) ondu zuenean, nahiz eta beste gauza batzuetan adostezinak ziren donostiarra eta bilbotarra (Kintana, 2008).

Barojak egiten du metaketa gaurko ikuspuntutik noragabea, batzuetan: irrintziak, kantak, esaerak, ohiturak, hitzak, landaredia, savoir-faire (kontrabandoa, nekazaritza...) Exotismo ukitua ere gustatzen zaio, maila berean (zirkoko freakak...): museolana, azken batean. Norbaitek esan lezake, agian, kontakizunaren bilbean ondo txertatuta datozela laginok, baina manierista eta barrokoegia suerta dakioke irakurleari. Jean Etxepare, aldiz, naturalagoa da, bakunagoa euskal mundua ispilatzean, euskal esentzia galkorrak jaso nahi izateko asmo mistikorik gabea.

Barojak ez zuen pentsatuko inondik ere ondare hori biziberritzerik edo indarberritzerik zegoenik, pesimista baitzen euskararen iraupenaz bezainbat beste gauza askotan, eta nahiz eta errazagoa izan historiak gerora hartuko zituen pleguak ezagutzea gaurko talaiatik begiratuta. Barojaren ideiategian, euskal aztarna linguistikoen bildumagilezaletasun hori izan daiteke adierazten zuen erruralismoaren beste seinale bat, modernitate berankorraren kontrako erreakzioz beretzakotu zuena, hiriaren eta, oro har, gizarte burges arrakastatsuaren itsusitasunaren aurrean. Berdenboran, izan daiteke euskal herritar xeheen ondarea jaso nahia Schopenhauerrek aldarrikatutako joera errukior karakteristikoaren seinalea eta garapena izatea, eta gizarteko sektore erregresiboen memoria kontserbatzera bultzatuko zuena. Nolanahi ere, Pío Barojak ere ezin izango zion itzuri egin Herderren itzal luzeari, orduko abertzaletasuna kritikatuagatik ere, zeinak Ernest Renanen nazio-ikuskera baztertzen zuen.

Jean Etxepareren ustez, aldiz, euskarak ordu hartan bazuen gizarte-eginkizuna, kontserbatuta egoteaz gain:

Odolarentzat amaren esnea bezala da arimarentzat arbasoen mintzaia: arbasoen arimako kar eta argia dakar. Argia laburra izan diteke; baduke auzoko argi biziago eta zabalago baten beharra; bainan tokiko argia baita, iluntzearekin, are gehiago itzaltzearekin, nahasten ditu toki hartako umeen urratsak, tokiaren amodioa hozten baitzakote berehala hango bizizaleer eta bertze toki baten alderako amodioa ezin baitzeie lot nekez baizik. Euskara ken haurrari: hil duzu haren baitan hastapeneko argiño hura, ahuldu dakozularik orozbat etxerako lehia, hautsi bere lurrarekilako lokarririk zailena, erdi eihartu Frantziaren beraren gerizatzera eta ontzera bere indarrez goiti zoan landare gazte bat (Charritton, 1984, 62. or.).

Jean Etxeparek Sarako Etxeberriren eta Paskual Iturriaga ilustratuaren bidea segitzen du. Pío Barojak, bere aldetik, ez du proposamen praktikorik euskararako, literaturgozamenetik harago. Jean Etxeparek bestela jokatu zuen Jon Casenavek tesian azaldu duenez, euskarazko irakurleak sustatuta, literatura idatziak hartzaileen euskarria izan zezan sistema egituratuago baten barruan (Casenave, 2002). 
Pío Barojak euskarak irauteko kezkarik ez zuen. Kontaktuko hizkuntza bien estatusari buruz, dio gaztelerak prestigioa duela gehiago, euskaraz naturaltasuna mintzo den artean. Zalacaín el aventurero euskal giroko eleberrian, Pío Barojak kanta herrikoiak darabiltza: euskara ahozkoa da beti (Baroja, 1909). Euskara, bestetik, erabilia da memento hunkigarrietan: maitaleen solasetan (Catalina/Zalacaín), Tellagorriren hilburukoan, eta antzekoetan, hau da, arrazoia/emozioa bikotearen banaketan, gaztelera arrazoiarekin lotuta, eta euskara emozioarekin. Oker ez bagaude, Etxepareren goraxeagoko aipuan ere nabaria da euskarak jasotzen duen interpretazio bihozkorra, haurtzaroarekin estuki lotua: frantsesa ere arrazoiaren eroalea litzateke, adibidez, Beribilezen Hegoaldetik bueltan Iparraldean sartzen direnean adierazi bezala:

Hargatik, mugaz hunaindiratu bezain laster, gozatu zaitala eta berritu zainetako bizia, hori ba. Jabalago barnea, hatsa hobeki hartzen dut. Bihotz-bihotzez eskualdun izan gatik, garaitiko nizan guzia frantsesa duketalakotz ez othe? Adimenduz eta buruz uste baino ere maiteago ez othe dugun guziek Frantzia? (Etxepare, 1931, 95. or.).

Jean Etxeparek, Beribilezen, euskal izenak daramatzaten herrien letreroak ere aipatzen ditu, alegia, kezka du euskara idatziarekiko; badakigu Etxeparek literatura idatziarekiko interesa zuela; Pío Barojari nekez antzematen zaio hizkuntzaren asmo normalizatzailerik. Ildo horretatik, Pío Barojaren gogokoa Bilintx zen, eta neurri apalagoan Juan Ignazio Iztueta, olerkari zereginetan bereziki, dirudienez, beti ere, ahozko literaturatik hurbilekoak, ez baitu euskal literatura idatzirik aipatzen, besteak beste gehiena erlijioso-utilitarioa zelako, beharbada.

Hala ere, bada autore bietan euskaldunaren isiltasunari edota mututasunari buruzko nortasun-ezaugarri komuna: ez Pío Baroja, ez Jean Etxepare ez omen ziren hiztun porrokatuak, bizi zirela. El vasco es alalo, zioen Pío Barojak; Beribilezen ere bada isiltasunaren onespena, Jean Etxeparek behin eta berriz hainbat pasartetara ekarria, dela protagonistaren dela beste bidaiarien ahotan.

Nolanahi ere, idazle bi hauen garaian polemika-giroa pil-pilean zegoen, euskararen kinkari eta etorkizunari buruz. Sabino Aranaren aldeko Aitzolek El Día egunkarian 1931n argitaratutako artikulu sortan («La muerte del euskera. Los intelectuales vascos o los profetas de mal agüero» izenekoa) eraso zion Unamunoren eszeptizismoaren adierazpide sonatuari («La muerte del euskera» izenekoa), euskararen etorkizunari buruz (Aldekoa, 2006):

En resumen, podría decirse que los «vascos del 98», con Ramiro de Maeztu a la cabeza, suscribieron con entusiasmo los planteamientos de Unamuno y que Sabino Arana y sus seguidores lo atacaron con acritud. Pío Baroja terció en la polémica cuatro días después del escándalo, con un artículo bastante crítico hacia los dos bandos enfrentados, pero su intervención, ejemplo de ponderación y buen sentido, pasó inadvertida entre las imprecaciones que unos y otros se dirigían (Baroja, 190108-31; Juaristi, 1987, 86. or.).

Pío Barojaren ikuspegi nostalgiko hutsa aipatu dugunez gero, gaineratu daiteke donostiarrak Julio de Urkixoren asmo euskaltzaleei«fantasía de filólogo» zeritzela: Urkixok 
euskara kultura-hizkuntza bilakatu nahi zuen, hizkuntzalaritzaren bitartekotzarekin (Urquijo, 1920). Barojaren ustez euskararena eginda zegoen, ez zegoen biziberritzerik ez eta garai hartako hizkuntzalarien ahaleginekin ere. Akaso, gogoratu behar da, akaso, mende hasiera hartan sortu zela Euskaltzaindia (1918) euskara batzeko helburu nagusiarekin. Euskal Pizkundea izenekoa abian zegoen, eta Olerkariak ezagutzera emango ziren. Pío Baroja arrotz zaio horri guztiari. Ez horrenbeste Jean Etxepare, euskaltzaleekin harremanetan baitzegoen, eta haien xedeak konpartitzen baitzituen, hein handi batean, hizkuntzaren artisau saiatua baitzen: lexiko-sorkuntzan ari zen, eta estilista gailenetakoa zen; Euskaltzaindiaren ateetan zegoen; hizkuntzalari eta filologoekin lankidetzan ari zen, etab.

Esan behar da Pío Barojak ez duela islatzen beti euskal komunitatea linguistikoki galtzearen arrangura eleberrietan, uste baitu prozesua itzuri ezina izanik horretaz gehiago kezkatzea ez dela zentzuduna. Adibidez, Tierra vasca trilogiako Zalacaín el aventurero eleberrian ikusten da nola protagonista euskaldunak bizitza-jokabide nietzschear bat eraman dezakeen, edozein kezka identitariotik urrun. Etxeparek, aldiz, diglosiaren eragin hazkorra laztuta somatzen du Beribilezen.

Ostera, euskara da Jean Etxepareren ikusmoldean talde-kohesioa sustatzen duen osagai bat, euskaldunen artean. Hori nabari da haren bizitzan Piarres Lafitterekin duen harremanean:

Adierazi dautazun arren etzirela iduripen bereko, berdin zure lagun on gelditzen niz, eskuararen alde (Xarriton, 1991) ${ }^{6}$.

Mediku laizistaren eta abadearen artean badira hainbat desadostasun, pentsamoldearen alorrean; bata agnostikoa bada eta zientzia positiboaren bultzatzaile, bestea atxikita dago zientziaren ikuspegi zaharkitu konfesional bati, Elizak oraindik urrats erabakiorrak egin behar baitzituen gaur egungo zientziaren bere onarpenera iristeko. Beraz, ezberdintasunak zituzten, adibidez, kosmologiaren alorrean. Etxepareren ikuspegiak planetaren sorrera eguzkitik bereiztutako «ziliporta» baten bidez azaltzen zuen bitartean, Lafittek Jainkoaren kreazioaren bidez azaltzen zuen. Gainerakoan ere beren filosofiahautuetan bide bereiz samarretatik jotzen zuten. Medikuak autore aleman sinesgabeak besarkatzen zituen bitartean (Nietzsche, Schopenhauer, Haeckel, Reichenbach), Lafittek nolabaiteko philosophia communis baten zalea zen, ziurrenez Akinoko Tomas Sainduan oinarria zuena; apaizak filosofia hori proposatzen zion Etxepareri onar zezan. Hala ere, euskararen aldeko lanean Etxeparek ikusten zuen aukera biek elkarrekin aritzeko, bizitzaren azkeneko bien arteko gutunerian haztatu daitekeenez (Xarriton, 1991). Izan ere, talde-kohesioak performantzia handitzen du (Reis \& Sprecher, 2009, 233. or.). Baziren adostasunak euskaldunen artean, oztopo argiak elkar ulertzeko, baina euskara trabak gainditzeko faktorea izan zitekeen Etxepareren begietan; hala ere, horrek bidesaria bazuen, zeren eta medikuaren bizitza guztiko lana izan zen desberdinen arteko tolerantzia hori defenditzea Eliza eta indar laikoak tema latzean zebiltzan garaian. 
Euskara kohesio-sortzailea da Beribilezen ere. Liburuan bada desadostasunik narratzailearen eta Loiolako santutegian solaskide duen apezñoaren artean. Biek eztabaidatzen dute Ignazio santuaren baitan zer ote den erabakigarriena, fedea ala adimena, edota biak batera. Narratzailearen ustez, Ignazio gizon jantzia zen unibertsitatean hainbat ikasketa egina zenez gero; apezñoarentzat Ignazioren baitan osagarri nagusia karra zen, ez adimena. Planteamendu horrek berriz ere gakartza erlijioaren eta zientziaren arteko medikuaren buruhauste nagusiaren altzora. Kontua da, gure hari honetarako, euskalduntasunak bien arteko anaitasuna bermatzen duela zein ere diren dituzten desadostasunak:

Guti haztatu dut ene bizian harena bezalako lañotasunik; eskualdun aneia batena zen, gainera gizon handizki argitu batena, fedezko khar ezti batek berotzen zuena eta sarkortzen orozbat (Etchepare, 1931, 57. or.).

Euskarak badu beste bertute bat: oroitzapen ona uztea: Ignazioren oinetxeko bisitan letrero bat euskaraz ikustean, poztu egiten da Etxepare:

Bat-batean paretan thindatu hitz batzuek jotzen dauzkitet begiak: eskuaraz dute jakinarazten hau dela San Ignazioren sor-etxea. Eta atsegin zait, atsegin handi, eskuaraz baitira. Doidoi, etxearen erakuslea eskuaraz mintzatu izan balitzaiku eskualduner, atzerritarrentzat idukiz erdara, orhoitzapen hobea baizik ez ginuken beiratu, hemen iragan minuta ezin-ahantzizkoez (Etchepare, 1931, 67. or.).

Garrantzitsua da oroitzapen onak gordetzea norberaren esperientzian, zeren eta oroitzapen onek gizakia esperientzia horiek berriz izatera sustatzen dute.

Alabaina, garai hartan bazen kinka bat ea euskara izan ote zitekeen bizimodu modernorako gai, ala hiltzen utzi behar ote zen. Auzi horrek bereizten zituen, adibidez, alde batetik, Etxepare, Azkue eta Lizardi bezalakoek eta, bestetik eta jakina denez, Baroja eta Unamuno bezalakoek, Euskal Herrian. Azkuek nahi zuen mendikotzat zeukan euskara hirira egokitu: hainbat ekintza burutu zituen Bilbon burges euskaldun-berriek euskaraz operak izan zitzaten, adibidez, eta gisa horretakoak, publiko bakoitzari bere neurriko hizkuntza-elikadura eskainiz (Kintana, 2002, 15-99. or.), haren asmoen erakusgarri soil bat aipatzearren.

Etxeparek ere euskara iraunarazi nahi zuen frantsesaren ekarpena baztertu gabe. Nahi zuen euskara egon zedin jende ikasien artamenduan, biziraun ahal izateko, eta betebehar hori nahitaezkoa ikusten zuen, edozein hizkuntzak garapen jasangarria izango bazuen. Ez zuen nahi euskara moral tradizionalak bizirauteko trikimailu bezala, sektore tradizionalek egiten zuenaren antzera; Azkue batek ere euskara herriaren osasun moralaren bermetzat jotzen zuen, nahiz eta beraren ikuspegia aurrerakoiagoa izan Elizako beste sektore batzuen asmoen aldean, euskara proiekzio modernorik gabe iraunarazi gurakoak. Etxeparek euskara nahi zuen orotariko gaiak jorratzeko gai, nahiz eta horrek buruhausteak ekarri zizkion idazle-praktikan (Kintana, 2001), lorpen ederrak eskuratuagatik idatzi zuen prosan. 
Etxepareren jarrera hein batean garbizalea bada ere, hautu linguistikoei gagozkiela, neologismoak eta hitz zaharkituak erabiltzeko gai bazen ere, orduko giroak manatuaren arabera, badaki euskararen etorkizuna homologazio kultural baten premian zegoela: Frantziatik zetorren kultura ezinbestekoa zitzaion. Honela dio Hegoaldetik bueltan autoan arnasten duen aireari buruz:

Menditik bulharretarat heldu zaikun aire sendoari hautemaiten diot, Frantzia guzitik harekin nahastekatzera jina, halako hazkurri arin, haztarik gabeko zer bat, osagarrizkoa hargatik, odoleratzeko gure lehenbiziko arbasoek etzuketena (Etchepare, 1931, 95. or.).

Izan ere, Etxeparek odola eta hizkuntza hurbiletik lotuak ikusten zituen, hizkuntzaren ikuspegi etnizista bat zuen, hori bai, gainditu eta molde berrietara isuri beharrekoa. Harentzat nabartar-odola zehatz lotua zegoen euskararekin, molde hori baitzerabilen euskaldunek hizkuntzari eusten ikusten zituenean (Etchepare, 1931, 38. or.).

Azkenik, euskarak iragankortasunaren izua ere sentiaraz diezaioke. Euskara harentzat bizitzaren metafora zen. Hizkuntzari egiten zaion erasoa gizakiaren izateari egiten zaion erasoa da, horregatik hizkuntza gutxituetako hiztunek diote atxikimendu berezia beren hizkuntzari, buru- eta gizarte-egituraren osagai bat da. Hizkuntza kulturaren arima da; hizkuntza erasotzean gizarte-loturari erasotzen zaio, hura hausteraino. Komunikabide nagusia da hizkuntza banako eta taldeen artean, komunikabiderik sotilena, doiena. Gizartea endekatu egiten da hizkuntza bertan behera uzten duenean, edo endekatzen denean. Aldi berean, banakoak aurrera egiten du hizkuntzaz gero eta gehiago jabetzen den heinean. Hizkuntza bat ezagutzeak pertsonaren eta taldearen bihotzean sartzen laguntzen du. Hizkuntzari erasotzea izateko moduari erasotzea da; aldiz, hizkuntza errespetatzea gizakia errespetatzea da. Izan ere, berarekin baitu indar berezi bat, izaera osoa besarkatzen duena. Sinbolo horrek zeinuak ernarazten ditu: bizitza baten partalier egiten du hiztuna (Chevalier \& Gheerbrant, 1969, 648. or.).

Etxeparek gudu hori sentitzen du laztasunez, urrutiago joan gabe Beribilezen.

\begin{abstract}
Ibañetako lepotik hunaratekoan, ohartu niz bertzalde herri bakotxak baduela bere etxeetarik bateko aitzin-paretan burdinazko-plaka xuri bat: huntan beltzez thindaturik herriaren bi izenak, bat erdarazkoa, bertzea mendeen mendez herritarrek ahoan zerabilaten eskuarazkoa.
\end{abstract}

Nori ere gogoratu baitzaio eskuararen alderako atxikimendu-seinale hori, bigarren lerroan ezarria bada ere eskuarazko izena, eskerrak hari!

Bainan, laztu nu eskuararen eta erdararen arteko guduaren ikusteak, burdin-zatiño hartan (Etchepare, 1931, 38. or.).

Bestalde, Beribilezeko beste pasarte batean, ezin ulertuta dabil nola euskal ama batek umeari euskaraz zuzendu dakiokeen (Etchepare, 1931, 34-35. or.), eta oso kezkatuta, 
bihotzaren erdira iristen zaiola. Belaunaldiz belaunaldiko transmisioa etetea harrigarria eta, aldi berean, kezkagarria begitantzen zaio.

Beribilezen ere, Loiolako bisitan, bertigoa sartzen zaio Ignazioren eskuizkribu irakurtezina ikustean, pentsatzen duenean santua bizi zela Azpeitiako kalean egiten zuen euskara ulertzeko gai izango ez ginatekeela-eta. Ikusten du Ignazioren eskuz idatzitako izkribu bat, higatua eta ia irakurtezina. Denboraren iraganak barkatzen ez duelakoa sentitzen du, hain zuzen, euskararen higadura eta aldaberatasunean islatuta. Euskararen patuarekin bat egiten zuen. Areago, kontuan izanda medikua gaixorik zegoela bihotzetik, eta urte gutxi zituela aurrera begira, berak bazekienez. «Euskera hilez gero, ez nuke nahi bizi» esaten zuen kanta herrikoi batek, garai batean...

\section{ONDORIOAK}

Ikusi ditugu Jean Etxepare eta Pío Baroja Azpeitiko zalduntxo ilustratuen bidetik, nahiz eta donostiarrak XIX. mendeko ukitu erromantikoa berea egin, adibidez bizitzaren filosofian Ameriketako itsasoa hobesten zuela Aldudeko mediku helduaren neurri neoklasikoaren ordez. Alabaina, oro har, bi biak saiatuko ziren egiaren bila, estereotipo atzerakoien kontra, zientziaren eta kulturaren aldeko lanean. Horiek parekotasunen multzoan.

Aldeak ere bazituzten. Pío Barojaren XIX. mendeko atxikimendua soma zitekeen euskararen ikuskizun paseistan ere. Euskara da donostiarrarentzat balio sentimentaleko museo-pieza maitagarria, etorkizuneko baliorik gabea, beharbada erruralismo batekin bat egina. Etxepare proaktiboagoa, hizkuntzari iraupena ematen bermatzerainokoan, nahiz eta gudu horren latza ez zaion itzurtzen. Esan behar da biek zituztela errezeloak goi burgesiak urratutako bideekin, iraultza modu zakar samarrean burutu zuela eta, euskal gizarte tradizionalaren ongaitzak kontuan hartu gabe.

\section{ERREFERENTZIAK}

Aldekoa, I. (2008). Euskal literaturaz hiru apunte solte. In Jean Haritschelhar-i omenaldia (1-15 or.). Bilbo: Euskaltzaindia.

Aldekoa, I. (2012). Ilustrazioa eta euskal literatura. ASJU, 42(2), 211-235.

Altonaga, K. (2006). Etxepare, Aldudeko medikua. Bilbo: Euskaltzaindia \& UPV/ EHU.

Apalategi, U. (2003). Hiriart Urrutyren harrera literarioari buruz: autoretzaren arazoa euskal literatura klasikoan. In B. Oyharçabal \& J. M. Makazaga (arg.), Euskal gramatikari eta literaturari buruzko ikerketak XXI. Mendearen atarian (15-31. or.). Euskaltzaindia: Bilbo.

Apalategi, U. (2004). Heziketa literarioaren kezka, Peñafloridatik Mogelera. Lapurdum, 9, 39-47.

Artola Renedo, A. (2009). La antimodernidad en el País Vasco: prácticas sociales y discursos (1765-1833). Cuadernos dieciochistas, 10, 121-147.

Azurmendi, J. (1999). Euskal Herria krisian. Donostia: Elkarlanean. 
Baroja, P. (1900). Vidas sombrías. Madril: Afrodisio Aguado.

Baroja, P. (1901-08-31). El vascuence, El Imparcial, 1.

Baroja, P. (1909). Zalacain el aventurero. Hemendik hartua: http://es.wikisource.org/ wiki/P\%C3\%ADo_Baroja

Baroja, P. (1917). Nuevo tablado de Arlequín. Madril: Caro Raggio.

Baroja, P. (1918). Cuatro libros: La historia de la creación natural de Ernesto Haeckel. In Las horas solitarias (201-212. or.). Madril: Rafael Caro Raggio.

Baroja, P. (1919). Momentum catastrophicum. Madril: Caro Raggio.

Baroja, P. (1920). Los contrastes de la vida. Madril: Rafael Caro Raggio.

Baroja, P. (2000). Opiniones y paradojas. Prólogo y selección de Miguel Sánchez-Ostiz. Madril: Caro Raggio.

Baroja, P. (2006 [1953]) El País Vasco. Tafalla. Txalaparta.

Baroja, P. (2006). Pío Barojaren Donostia. Irun: Alberdania.

Baroja, P. (2007). Ipuinak. Donostia: Gipuzkoako Foru Aldundia.

Baroja, P. (2010). Itzaleko biziak. Donostia: Hiria.

Baubérot, J. (2004). Laicité. In M. Canto-Sperber (zuz.), Dictionnaire d'éthique et de philosophie morale (1059-1066. or.). Paris: PUF.

Bello Vázquez, F. (1990). El pensamiento social y político de Pío Baroja. Salamanca: Universidad de Salamanca.

Bidegain, E. (2013). Lehen mundu gerra Eskualduna astekarian. Bilbo: Euskaltzaindia.

Boyer, A. et al. (1991). Pourquoi nous ne sommes pas nietzschéens. Paris: Éditions Grasset.

Casenave, J. (2002). De l'article de presse à l'essai littéraire: Buruchkak (1910) de Jean Etchepare. Madril: UNED.

Casenave, J. (2003). Ramuntcho, Pierre Loti-ren sartzea Euskal Herrian. In B. Oyharçabal \& J. M. Makazaga (arg.), Euskal gramatikari eta literaturari buruzko ikerketak XXI. Mendearen atarian (69-79. or.). Euskaltzaindia: Bilbo.

Charritton, P. (arg.). (1984) Jean Etchepare mirikuaren idazlanak I. euskal gaiak. Donostia: Elkar.

Charritton, P. (arg.). (1985) Jean Etchepare mirikuaren (1877-1935) idazlanak. II mediku-solas. Donostia: Elkar.

Charritton, P. (arg.) (1988). Jean Etchepare mirikuaren (1877-1935) idazlanak. III kazetaritza (A) (1916-1935). Donostia: Elkar.

Charritton, P. (arg.). (1992) Jean Etchepare mirikuaren (1877-1935) idazlanak. IV kazetaritza (B) (1916-1935). Donostia: Elkar.

Charritton, P. (arg.). (1996) Jean Etchepare mirikuaren (1877-1935) idazlanak. V Euskalerriko bizia (1932-1935). Donostia: Elkar.

Chevalier, J. \& Gheerbrant, A. (1969) Dictionnaire des symboles. Paris. Robert Laffont.

Delvaux, M. \& Caron, P. (2010). Postcolonialisme. In P. Aron, D. Saint Jacques \& A.

Viala (zuz.), Le dictionnaire du littéraire (601-603. or.). Paris: PUF.

Dufau, D. (1950a). Ganichen makhila. Gernika, 12, 25-27.

Dufau, D. (1950b). Ganischen (sic) ordainbidea. Gernika, 13, 30-31.

Elkar-lanean. (1972). Pio Baroja bere ehunurteburuan: 1872-1972. Bilbo: Etor.

Epicteto (2015). Disertaciones por Arriano. Madril: Gredos.

Etchepare, J. (1910). Buruchkak. Tours: Imprimerie Mame. 
Etchepare, J. (1984). Euskalzaleen biltzarraren xedeak eta sail berria Maulen (1922). In P. Charritton (arg.), Jean Etchepare mirikuaren idazlanak I. euskal gaiak (61-68. or.). Donostia: Elkar.

Etchepare. J. (1931). Beribilez. Baiona: Laserre.

Fernández, J. (2006). Ser humano en los conflictos. Madril: Alianza Editorial.

Gartzia Trujillo, S. (2014). Jean Etxepare, Aldudeko medikua. Euskal modernitatearen brankako irudia. Bilbo: Desclée de Brower.

Gartzia, P. (2015). Berrirakurketa historiko bat: Peru Abarka (1802). Kondaira, 11, 47-51.

Gasnier, Th. (1984-1992). Le local. In P. Nora (arg.), Les lieux de la mémoire (III, 3423-3476 or.). Paris: Gallimard.

Guillén, C. (1985). Entre lo uno y lo diverso: Introducción a la literatura comparada. Bartzelona: Crítica.

Heit, H. (2012). Verdad. In Ch. Niemeyer (arg.), Diccionario Nietzsche. Conceptos, obras, influencias y lugares (521-523. or.). Madril: Biblioteca nueva.

Jankélévitch, V. (1964). L'ironie. Paris: Champs-Essais.

Juaristi, J. (1987). Literatura vasca. Madril: Taurus.

Kinder, H., Hergt, M. \& Hilgemann, W. (2007). Atlas histórico mundial. Madril: Ediciones AKAL.

Kintana, J. (2001). Nietzsche euskal literaturan: Jean Etchepareren «Amodioa» (1910). Jakin, 127, 109-128.

Kintana, J. (2002). Vizcaytik Bizkaira? R. M. Azkue Euskaltzaindia sortu aitzin(1888-1919). Bilbao: BBK Fundazioa \& Euskaltzaindia.

Lafitte, P. (1980 [1941]). Jean Etchepare jaun mirikua (1877-1935): aitzin-solas. In J. Etxepare, Buruxkak (5-21. or.). Donostia: Elkar.

Lafitte, P. (1974). Mende huntako euskaldun idazleen pentsa-bideak. Baiona: Imprimerie des Cordeliers.

Le Rider, J. (1999). Nietzsche en France: de la fin du XIX siècle au temps présent. Paris: PUF.

López Antón, J. J. (1998). El imaginario pesimista de Vasconia en Arturo Campión. Vasconia, 27, 177-194.

Lorenzo Arza, M. (2017). Las fuentes regionalistas de la Castilla noventayochista. Eskuizkribua. Hemendik eskuratua: https://www.academia.edu/31012783/ Las_fuentes_regionalistas_de_la_Castilla_noventayochista

Loti, P. (1897). Ramuntcho. Édition du groupe «Ebooks libres et gratuits». Hemendik eskuratua: https://www.ebooksgratuits.com/pdf/loti_ramuntcho.pdf

Michelena, L., \& Altuna, F. (1972). Mitxelenaren idazlan hautatuak: Idazlanen aukera oharrak, iruzkinak. Bilbo: Mensajero.

Mitxelena, K. (1955). Pío Barojak esan digu. Egan, 3-4, $1-4$.

Mitxelena, K. (2001). Pío Baroja. In Gure artean (239-244. or.). Zarautz: Alberdania.

Niemeyer, C. (arg.). (2012). Diccionario Nietzsche. Conceptos, obras, influencias y lugares. Madril: Biblioteca Nueva.

Ortiz de Pinedo, A. (2011). Euskal literatura Gernika aldizkari liberalean: 1945-53. Amorebieta: Erroteta.

Ortiz de Pinedo, A. (2018). Jean Etxepareren Beribilez (1931): bidaia eta ideologia. Defentsa-bidean den tesia. 
Pageaux, D.-H. (1989). De l'imagerie culturelle à l'imaginaire. In P. Brunel \& Y. Chevrel (arg.), Précis de littérature comparée (133-161. or.). Paris: PUF.

Pinto, L. (1995). Les neveux de Zarathustra. La réception de Nietzsche en France. Paris: Seuil.

Placer, E. L. (1958). Lo Vasco en Pío Baroja. LSU Historical Dissertations and Theses. Hemendik eskuratua: http://digitalcommons.lsu.edu/gradschool_disstheses/499

Placer, E. L. (1968). Lo vasco en Pío Baroja. Buenos Aires: Ekin.

Reis, H. T. \& Sprecher, S. (arg.). (2009). Encyclopedia of Human Relationships: Vol. III. California: Sage.

Rogers, L. \& Aronson, J. (2013). Sterotype threat. In S. J. Lopez (arg.), The encyclopedia of positive psychology (936-939. or.). Oxford: Wiley-Blackwell.

Sánchez Granjel, L. (1953a). Vasconia en la literatura barojiana. Índice de Artes y Letras, 9(70-71), 5.

Sanchez Granjel, L. (1953b). Presencia de Vasconia en la vida y en las obras de Pío Baroja. $B A P, 9,155-167,363-387$.

Schaer, R. (2004). Patrimoine. In M. Canto-Sperber (zuz.), Dictionnaire d'éthique et de philosophie morale (1404-1408. or.). Paris: PUF.

Schröder-Abé, M. \& Schütz, A. (2007). Collective Self. In R. F. Baumeister \& K. D. Vohs (arg.), Encyclopedia of social psychology (154-155. or.). California: Sage Publications.

Simmel, G. (1903). La metrópolis y la vida mental. Bifurcaciones, 4.

Sobejano, G. (1967). Nietzsche en España. Madril: Gredos.

Sobejano, G. (2004). Nietzsche en España, 1890-1970. Madril. Gredos.

Stangor, Ch. G. (1995). Sterotyping. In A. Manstead \& M. Hewstone (arg.), The Blackwell Encyclopedia of Social Psychology (628-633. or.). USA: Blakwell.

Urquijo, J. (1919). Lengua internacional y lenguas nacionales: el euskera, lengua de civilización. RIEV, 10(2), 164-180.

Ury, W. (1999). Getting to peace: Transforming conflict at home, at work, and in the world. New York: Viking Press.

Weber, E. (1983). La fin des terroirs. La modernisation de la France rurale 1870-1914. Paris: Fayard.

Xarriton, P. (1991). Jean Etchepare jaun mirikuak Piarres Lafitte jaun apezari idatzi zenbait gutun (1924-1935). In J. A. Lakarra J. A. \& I. Ruiz Arzallus (arg.), Memoriae L. Mitxelena magistri sacrum. Pars prior (595-604. or.). Donostia: Gipuzkoako Foru Aldundia.

Xarriton, P. (1995). Fonds Lacombe: les lettres du docteur Jean Etxepare (2-6-1905; 4-3-1932). Bulletin du Musée Basque, 140, 49-100. 